\title{
IDENTIFIKASI MOTIF LOKAL SARUNG MAJALAYA GENERASI PERTAMA
}

\section{THE INDIGENOUS MOTIF IDENTIFICATION ON FIRST GENERATION OF SARUNG MAJALAYA}

\author{
Endah Oktaviani $^{1}$, Agus Sachari ${ }^{2}$, Pindi Setiawan ${ }^{3}$ \\ ${ }^{1}$ Program Studi Magister Desain, Institut Teknologi Bandung Jalan Ganesa No. 10 Bandung \\ E-mail: eosyidik@gmail.com \\ ${ }^{2}$ Program Studi Magister Desain, Institut Teknologi Bandung Jalan Ganesa No. 10 Bandung \\ E-mail: agus_sachari@fsrd.itb.ac.id \\ ${ }^{3}$ Program Studi Magister Desain, Institut Teknologi Bandung Jalan Ganesa No. 10 Bandung \\ E-mail: pindisp@yahoo.com
}

Tanggal diterima : 26 September 2016, direvisi : 8 Maret 2017, disetujui terbit : 17 Maret 2017

\begin{abstract}
ABSTRAK
Sarung adalah produk utama industri tekstil Majalaya yang sempat populer di seluruh Indonesia serta beberapa negara Asia. Sistem maklun yang dijalankan para perintis industri tekstil generasi pertama dalam proses bisnisnya menyebabkan mereka tidak mampu bertahan dari penetrasi pasar, sedangkan identitas motif lokal sarung Majalaya semakin terlupakan. Penelitian ini bertujuan untuk mengidentifikasi motif-motif lokal yang muncul di kalangan produsen sarung pada tahun 1930-1970. Metode kualitatif dengan pendekatan folklor non-lisan ditempuh untuk menggali kenangan masa lalu mengenai motif-motif lokal Majalaya dan dituangkan dalam rekonstruksi visual yang bersifat re-kreasi berdasarkan penuturan narasumber. Hasil penelitian ini adalah ditemukannya motif poléng sebagai motif lokal yang pernah muncul di Majalaya tahun 1930-1970 dengan nomenklatur variasi sarung poléng Majalaya yakni: poléng camat, poléng haji, poléng totog, poléng bolégbag, poléng taliktik, poléng namicalung. Motif poléng merupakan aplikasi dari motif dasar desain struktur yang termasuk kedalam kategori garis dan kotakkotak. Kategori motif dasar desain struktur yang digunakan di Majalaya pada masa tersebut antara lain kategori desain kotak yang dibentuk dari garis benang, desain garis horisontal, desain kotak teratur, dan desain plaid. Rekonstruksi visual melalui folklor non-lisan dapat diaplikasikan untuk pengungkapan motif lokal yang tidak tersedia sumber visualnya.
\end{abstract}

Kata kunci : majalaya, motif lokal, rekonstruksi visual, sarung poleng, folklor non-lisan

\section{ABSTRACT}

Sarung is Majalaya's main product which becomes popular all over Indonesia and several Asian countries. Makloon system runned by the first generation of textile pioneers as their business process made them failed to survive on the market penetration, while indigenous local motif of sarung Majalaya became forgotten. This study aims to identify the indigenous motif that appears among sarung producers in 1930-1970. Nonverbal folklore method was used to retrieve past memories on indigenous motifs and delivered through recreation visual reconstruction from informan's words. The results are, the appearance of poléng motif as indigenous motif known at Majalaya in 1930-1970 along with variation of sarung poléng nomenclatures found: poléng camat, poléng haji, poléng totog, poléng bolégbag, poléng taliktik, and poléng namicalung. Poléng motifs applied from structure design motifs which are categorized as stripes and checks design, such as: checked motif from yarn's line, horizontal stripe, uniform checks, and plaid design. Non-verbal folklore can be used as visual reconstruction to reveal indigenous motifs that lack of visual sources.

Keywords: majalaya, indigenous motifs, visual reconstruction, sarung poleng, non-verbal folklore

\section{PENDAHULUAN}

Tradisi menenun di Jawa Barat sudah dikenal sejak ratusan tahun yang lalu. Istilah "upageuning" yang tertulis dalam naskah kuno Sanghyang Siksa Kandang Karesian mengungkapkan bahwa masyarakat Jawa Barat sudah mengenal kesopanan dalam berbusana ${ }^{1}$. Salah satu daerah penghasil sarung tenun di Jawa Barat adalah Majalaya.
Kegiatan pertenunan di Majalaya sudah ada sejak awal tahun 1920, namun pada masa tersebut menenun masih merupakan sebuah tradisi yang dilakukan oleh para wanita dengan menggunakan alat tenun tangan yang dikenal dengan sebutan "kentreung". Para wanita duduk di bale-bale rumah dan menenun kain bodasan (belacu) dan stagen menggunakan bahan baku benang kapas yang dipintal secara manual. ${ }^{2}$ 
Generasi pertama industri pribumi muncul di tahun 1930-an dan didominasi oleh golongan juragan yakni golongan tuan tanah yang mengenyam pendidikan (Gambar 1). Masuknya aliran listrik di wilayah Majalaya menyebabkan peralihan teknologi tekstil dari alat tenun manual (handloom) menjadi alat tenun mesin (powerloom). Hingga tahun 1937, industri sarung telah berkembang sangat pesat dan menguasai $47 \%$ keseluruhan suplai sarung, dan industri kecil menengah yang sangat pesat kemajuannya adalah Majalaya., ${ }^{3,4}$ Dengan adanya peralihan teknologi tersebut menyebabkan terjadinya perubahan perubahan yang mendasar yang disebabkan oleh perbedaan prinsip dan konsep yang dimiliki masing-masing teknologi seperti yang tercantum dalam Tabel 1.5

Ragam hias pada produk tekstil pada dasarnya tercipta dari desain struktur (structure design) dan desain permukaan (surface design). Desain struktur sifatnya lebih terbatas pada pengolahan unsur-unsur pembentuk konstruksi kain, serta dibatasi oleh jenis alat/mesin yang digunakan, karakter material bahan baku, serta susunan kain ${ }^{6}$. Dari penelitian sebelumnya ditemukan bahwa perkembangan motif tenun di Majalaya tidak muncul dari kekhasan ragam hias sebagaimana dimiliki oleh daerah lain, melainkan merupakan hasil fisik yang terbentuk dari penggunaan teknologi tenun yang berkembang di Majalaya ${ }^{7}$. Perkembangan motif kain sarung di Majalaya terjadi akibat peralihan teknologi pertenunan yang berkembang dalam periode tertentu. Jenis teknologi tersebut memungkinkan terjadinya perubahan / variasi bentuk dan motif yang mampu dihasilkan. Teknologi tenun yang berkembang sebelum listrik masuk Majalaya antara lain kentreung (alat tenun tangan) serta tustél (ATBM), sedangkan teknologi tenun berbasis listrik yang mulai digunakan tahun 1935 diantaranya ATM jenis teropong (shuttle loom) dan ATM Rapier. Teknik pembuka mulut lusi dobby dan jacquard yang dulunya hanya diaplikasikan pada kain busana mulai dikembangkan untuk menciptakan motif-motif yang lebih menarik dan rumit. Desain motif sarung Majalaya pada dasarnya berbentuk garis/salur dan kotak-kotak dengan warna yang mencolok. Motif tersebut merupakan aplikasi dari desain struktur pada kain tenun. Pada Tabel 2 dipaparkan kategori desain motif garis (stripes) dan kotak-kotak (check) yang Peneliti kaji dari dua literatur yang berbeda ${ }^{6,8}$

Untuk menciptakan motif garis dan kotak yang melintang pada kain sarung dengan permainan warna yang berbeda, dibutuhkan beberapa teropong dengan warna benang pakan yang berbeda kemudian ditempatkan pada sebuah laci/ bak teropong sehingga nantinya secara mekanis dapat bekerja bergantian sesuai dengan desain yang diinginkan. Mekanisme tersebut dikenal dengan istilah pertukaran bak atau wesel bak, yang diciptakan oleh Robert Kay. Klasifikasi mesin tenun dengan mekanisme pertukaran bak dibedakan menjadi: (1) mesin tenun dengan pertukaran bak satu sisi, biasanya dinyatakan dengan 2x1, 4x1, dan seterusnya; dan (2) mesin tenun dengan pertukaran bak dua sisi yang biasanya dinyatakan dengan 2x2, 3x3, dan seterusnya. Yang lazim digunakan pada industri tekstil di Indonesia adalah mesin tenun pertukaran empat bak pada satu sisi (4 shuttle change device) seperti mesin Suzuki tipe $\mathrm{A}^{9}$.

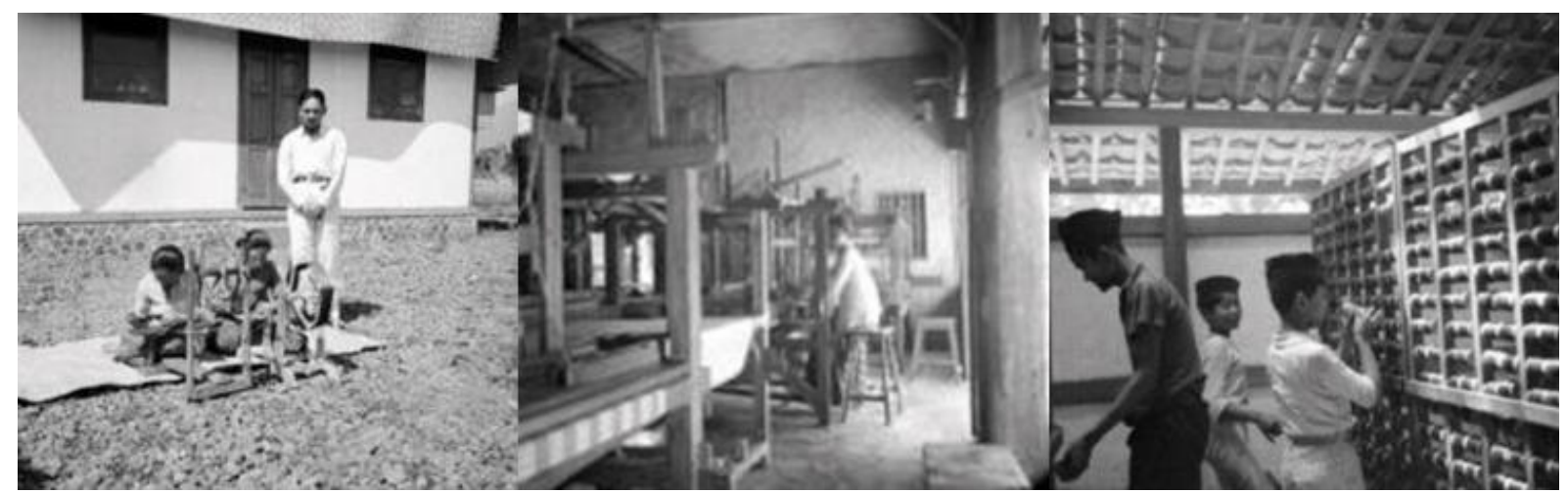

Gambar 1. Industri tenun rumahan di Majalaya tahun 1930-an (Sumber: Tropenmuseum) 
Tabel 1. Perbedaan Handloom dan Powerloom ${ }^{5}$

\begin{tabular}{lll}
\hline \multicolumn{1}{c}{ Prinsip/konsep } & \multicolumn{1}{c}{ Hand Loom } & \multicolumn{1}{c}{ Power Loom } \\
\hline Sistem operasi & Manual & Listrik \\
Pembukaan mulut lusi (shedding) & Menggunakan pedal & Otomatis \\
Peluncuran benang pakan (picking / filling) & Manual & Otomatis \\
Kapasitas Produksi & Rendah & Tinggi \\
Kecepatan & Lambat & Cepat/tinggi \\
Investasi Awal & Kecil / Murah & Besar / Mahal \\
Desain & Sederhana & Kompleks \\
Sifat Produksi & Terbatas & Massal \\
\hline
\end{tabular}

Tabel 2. Kategori Motif Garis dan Kotak-kotak Pada Kain Tenun ${ }^{8,10}$

\begin{tabular}{|c|c|c|}
\hline Kategori Motif & Jumaeri,dkk. (1974) & Zheng (2013) \\
\hline $\begin{array}{l}\text { Desain Garis } \\
\text { (Stripes) }\end{array}$ & $\begin{array}{l}\text { 1. Desain strip horisontal (ke } \\
\text { arah pakan) } \\
\text { 2. Desain strip vertikal (ke arah } \\
\text { lusi) } \\
\text { 3. Desain strip miring } \\
\text { 4. Desain strip teratur } \\
\text { 5. Desain strip tak teratur }\end{array}$ & $\begin{array}{l}\text { 1. Desain garis vertical } \\
\text { 2. Desain garis horizontal } \\
\text { 3. Desain garis miring (oblique) } \\
\text { 4. Desain garis bergelombang (wavy) }\end{array}$ \\
\hline $\begin{array}{l}\text { Desain Kotak } \\
\text { (Check) }\end{array}$ & $\begin{array}{l}\text { 1. Desain kotak teratur } \\
\text { 2. Desain kotak tak teratur } \\
\text { 3. Desain kotak yang dibentuk } \\
\text { oleh garis benang }\end{array}$ & $\begin{array}{l}\text { 1. Pola seragam (uniform checked pattern) } \\
\text { 2. Pola tidak seragam (non-uniform checked } \\
\text { pattern) }\end{array}$ \\
\hline $\begin{array}{l}\text { Desain Kombinasi } \\
\text { / Campuran } \\
\text { (Compound) }\end{array}$ & 1. Desain Plaid & $\begin{array}{l}\text { 1. Garis dan kotak sebagai grid dan diisi } \\
\text { dengan motif lainnya atau menyusun motif } \\
\text { secara berulang dalam posisi berjajar. } \\
\text { 2. Garis dan kotak sebagai latar, dengan } \\
\text { penambahan motif lainnya } \\
\text { 3. Motif bunga/ hewan diposisikan sebagai } \\
\text { motif utama, sedangkan motif garis dan kotak } \\
\text { yang timbul dari anyaman sebagai latar. } \\
\text { Perbedaan dengan tipe (2) yakni tidak adanya } \\
\text { motif yang jelas di bagian latarnya, } \\
\text { karena fokusnya hanya menciptakan motif } \\
\text { aneka warna bukan memberi kesan perbedaan } \\
\text { layer. }\end{array}$ \\
\hline
\end{tabular}

Sistem makloon yang berkembang di Majalaya menyebabkan terjadinya proses bauran ragam hias daerah lain, sehingga semakin menenggelamkan motif lokal yang pernah populer di Majalaya. Kondisi ini hampir sama dengan yang terjadi di sentra tenun Troso, yang kehilangan identitas motif lokal daerahnya karena terlalu menggantungkan kegiatan produksi melalui sistem makloon. Oleh sebab itu, penelitian yang membahas secara mendalam mengenai desain motif sarung
Majalaya masih sulit ditemukan. Beberapa penelitian sebelumnya hanya membahas sejarah industri tekstil Majalaya, kondisi buruh tekstil, permasalahan industri tekstil Majalaya, serta sarung songket Majalaya. Dengan latar belakang tersebut maka Penelitian ini bertujuan untuk menelusuri serta mengidentifikasi motif-motif lokal yang pernah muncul di kalangan produsen sarung generasi pertama, yakni perintis industri sarung yang muncul pada tahun 1930-1970. 


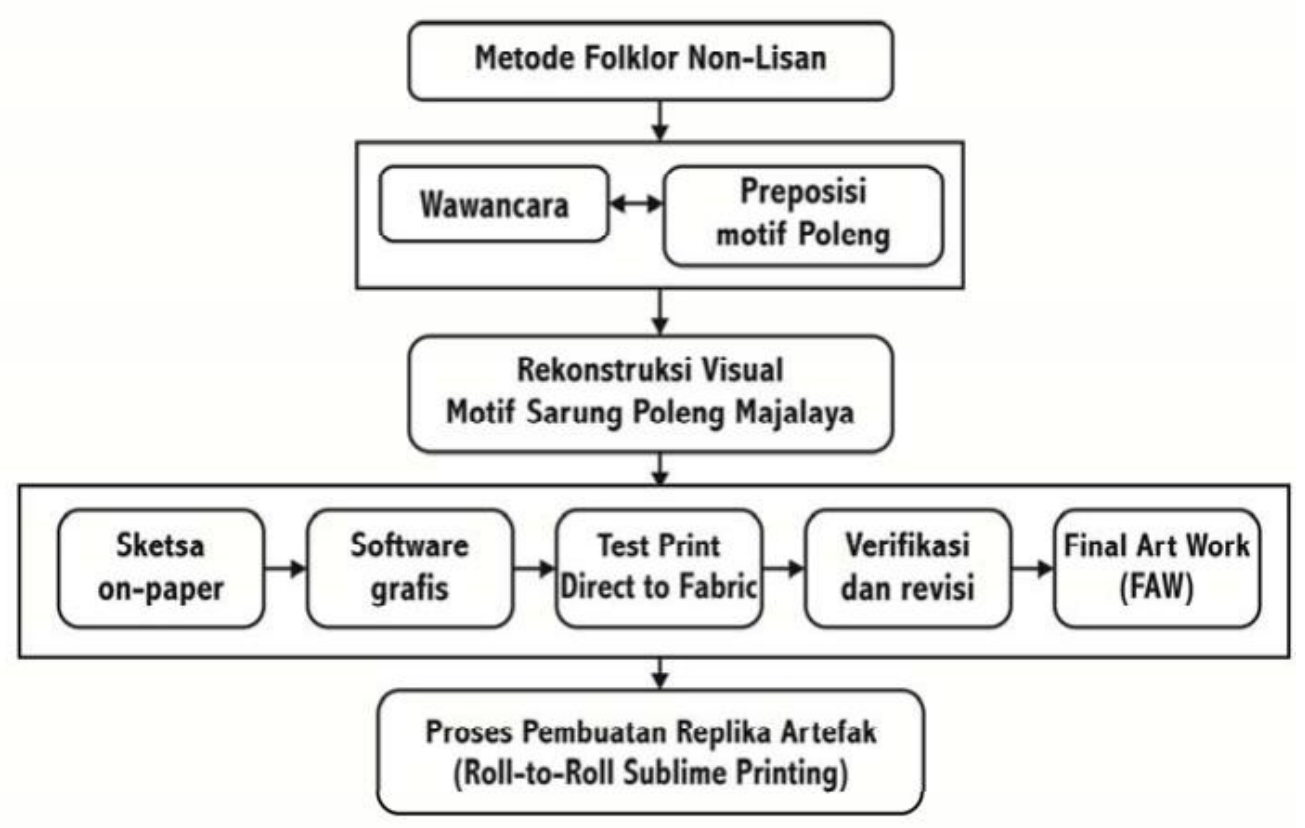

Gambar 2. Diagram alir penelitian

\section{METODE}

Pendekatan penelitian sejarah dengan menggunakan metode folklor non-lisan (non-verbal folklore method) dipilih karena pada dasarnya kerajinan tekstil merupakan salah satu benda folklor non-lisan yang teknik pembuatan dan pengetahuannya diturunkan melalui ucapan lisan dari generasi sebelumnya. Metode ini dapat digunakan ketika sumber visual yang ada di lapangan sulit ditemukan. Dalam metode ini, dasar utama yang menjadi prioritas adalah ingatan para pelaku sejarah. Ingatan tersebut kemudian dikeluarkan (retrieval) melalui teknik wawancara mendalam (in-depth interview) dan hasilnya merupakan sebuah rekonstruksi visual dari apa yang sesungguhnya ada di masa lampau ${ }^{10,11}$. Peneliti menuangkan rekonstruksi visual sebagai upaya re-kreasi dari motif yang ada di masa lalu, bukan merupakan imajinasi (kreasi) bebas penciptaan produk baru ${ }^{11}$. Kegiatan penelitian digambarkan melalui diagram alir Gambar 2.

\section{Penentuan kriteria dan seleksi informan}

Kriteria yang ditentukan antara lain:

(1) Informan merupakan pelaku sejarah, keturunan langsung pelaku sejarah atau tokoh masyarakat di Majalaya, yang hidup pada periode 1930-1970;

(2) Sehat secara fisik dan tidak menderita hilang ingatan;

(3) Bersedia memberikan informasi yang dibuktikan dengan menandatangani formulir kesediaan menjadi narasumber.

\section{Persiapan media dan sarana penunjang yang akan digunakan}

Media yang digunakan dalam proses revisualisasi adalah kertas milimeter block $\mathrm{A} 3$, alat tulis, penggaris, dan pensil warna. Sebagai media bantu ingat (mnemonic devices) disediakan sarungsarung dengan variasi ukuran kotak, variasi bentuk garis, dan variasi warna. Sarung dipilih secara acak baik hasil produksi asli Majalaya dan sarung dari brand terkenal seperti Gajah Duduk, Wadimor, Sapphire, Sarung Manggis, dan Sarung Atlas.

Penelitian dilakukan melalui tiga tahap utama. Tahap pertama, kegiatan penelusuran sumber tertulis untuk mencari informasi awal mengenai keberadaan motif lokal sarung Majalaya. Sumber tertulis yang dicari mencakup dokumen berita surat kabar, dokumen Keppres/SK, dan laporan penelitian sebelumnya. Kegiatan ini dilaksanakan di Monumen Pers Surakarta, Bapusipda Provinsi Jawa Barat, dan Museum Nasional Jakarta. Hasil penelusuran sumber tertulis kemudian dijadikan dasar pertanyaan pada tahap kedua, yaitu sesi wawancara mendalam dengan beberapa tokoh industri tekstil Majalaya, instansi pemerintah, dan tokoh masyarakat. Pengumpulan data dilakukan menggunakan teknik snowball data collecting. Dalam wawancara mendalam, Peneliti melakukan verifikasi hasil temuan sumber tertulis, dan mengumpulkan nama motif-motif lokal sarung Majalaya yang pernah muncul di Majalaya periode tahun 1930-1970. Tahap ketiga adalah kegiatan rekonstruksi visual motif sarung Majalaya berdasarkan penuturan informan yang dipilih yaitu H. Satya Natapura dan H. Sawali. Kedua informan dipilih karena sesuai dengan kriteria yang 
ditentukan. Langkah-langkah kegiatan visualisasi sarung dapat dijabarkan sebagai berikut:

(1) Kegiatan rekonstruksi visual motif sarung dilakukan di kediaman informan (Gambar 3).

(2) Sebelum mulai, informan diberikan penjelasan umum mengenai latar belakang dan tujuan kegiatan rekonstruksi visual sarung, ruang lingkup jenis motif sarung yang akan direvitualisasi, serta detail langkahlangkah yang akan ditempuh.

(3) Satuan yang digunakan selama kegiatan ini adalah satuan $\mathrm{cm}$ (centimeter).

(4) Peneliti melakukan sketsa pada kertas milimeter block sesuai penjelasan dari informan. Sketsa kasar yang selesai dikerjakan kemudian diperiksa dan direvisi. Tandatangan dibubuhkan sebagai penanda persetujuan informan.

(5) Peneliti memindahkan sketsa kedalam bentuk vector menggunakan software grafis Coreldraw dan Adobe Photoshop, untuk memperoleh gambaran anyaman motif sarung yang lebih detail.

(6) Peneliti membuat testprint motif dengan teknik DTF (Direct to Fabric) diatas kain katun dan polyester BSY ukuran 30x30 cm.

(7) Hasil testprint dibawa kembali ke Majalaya untuk diverifikasi oleh informan. Informan memberikan revisi akhir.

(8) Final Art Work (FAW) motif sarung diprinting dengan menggunakan teknik Rollto-Roll Sublime Heat Transfer untuk memindahkan motif ke atas kain jenis polyester BSY dengan ukuran setengah sarung $(105 \times 125 \mathrm{~cm})$. Teknik ini dianggap mampu menyajikan detail anyaman tenun secara optimal dibandingkan sistem DTF yang sebelumnya digunakan.

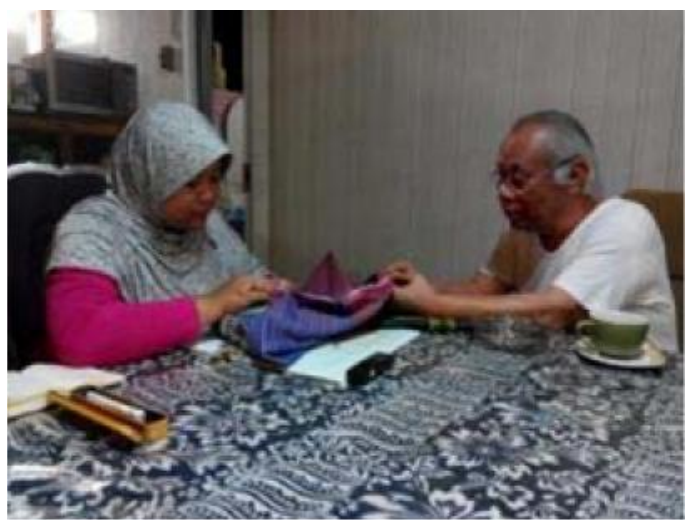

(a)

\section{HASIL DAN PEMBAHASAN}

Dalam perjalanan perkembangan industri pertenunan sarung di Majalaya, dikenal empat corak dasar yang muncul dikalangan pengusaha tenun sarung. Corak Palembangan muncul pada tahun 1920-an, sebagai sebutan untuk sarung yang diajarkan oleh seorang perantau dari Palembang bernama Kiagoes Samman. Corak Polekat muncul sebagai sebutan motif sarung di wilayah Majalaya yang meniru sarung polekat hasil produksi Preanger Bontweverij atau Paberik Tenun Garut (PTG) pada tahun 1932. Seiring dengan meningkatnya tren sarung dikalangan busana pria, maka perluasan pasar keluar daerah Pulau Jawa mulai dilakukan oleh pengusaha pribumi. Diyakini bahwa sejak tahun 1935 hal ini telah tumbuh, hal ini dibuktikan dengan dikenalnya istilah "poléng sebrang" yang dimunculkan oleh perusahaan Saudara Oesaha milik H. Abdoelgani. Adanya peluang untuk mereplika motif dari luar daerah tersebut mengarahkan pada kemunculan istilah "Corak Bugisan" dan "Corak Samarindaan".Corak Bugisan mengadopsi corak sarung sutera dari Mandar/Makassar, sedangkan Corak Samarindaan mengadopsi karakter dan corak sarung sutera dari Kalimantan.Keempat corak dasar tersebut menjadi awal pengembangan motif sarung poléng di Majalaya, dan dalam perjalanannya terus diaplikasikan dan dikembangkan pada motif sarung Majalaya masa kini.

Dari hasil penelusuran sumber tertulis ditemukan pula beberapa nama-nama motif poleng antara lain poléng dangdeur digerus, poléng simping, dan poléng seberang. Keberadaan motifmotif tersebut secara fisik tidak ditemukan, dan saat diverifikasi dengan narasumber ditemukan bahwa motif poléng yang disebutkan tersebut bukan merujuk pada desain motif. Poléng dangdeur digerus adalah suatu teknik penyempurnaan kain sarung dengan cara digerus (digosok) di atas meja dengan menggunakan kulit cangkang kerang atau lilin. Poléng simping adalah

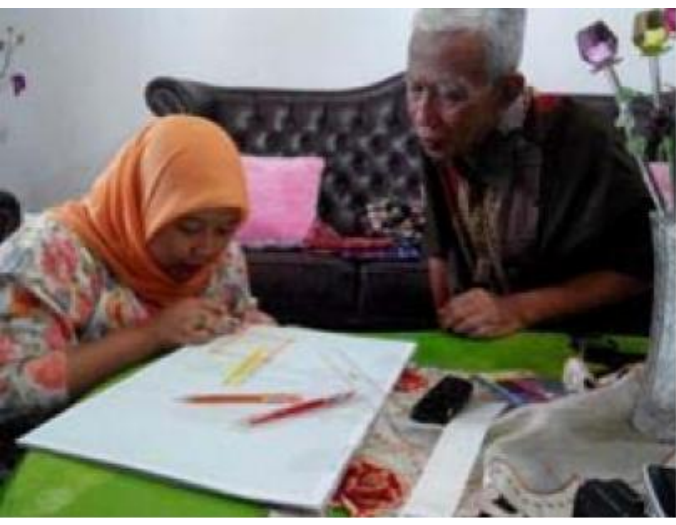

(b)

Gambar 3 a. Kegiatan rekonstruksi visual di kediaman H. Satya Natapura (kiri); b . kediaman H.Sawali (kanan) 
istilah motif poléng yang dibuat satu sisi (setengah) kemudian direpetisi dengan teknik mirror sehingga sisi kiri dan kanan terlihat sama besar. Poléng sebrang adalah istilah motif-motif poléng yang dibuat untuk memenuhi permintaan dari luar Majalaya.

Melalui proses wawancara mendalam, ditemukan bahwa motif poléng Majalaya berbeda dengan poleng Bali. Selain perbedaan fungsi dan filosofinya, poleng Majalaya diyakini berasal dari kosa kata Bahasa Sunda "coréléng” yang artinya belang-belang. Menurut H. Satya, istilah ini dipakai karena teknik merancang motif sarung di atas kertas biasanya bermula dari coretan-coretan cat warnawarni. Motif poléng muncul sebagai preposisi motif lokal khas Majalaya, dan dikenal dengan sebutan "Poléng Majalaya". Setidaknya terungkap enam nama motif poleng yang muncul di kalangan produsen sarung Majalaya generasi pertama pada tahun 1930-1970. Atas dasar preposisi tersebut Peneliti melakukan teknik rekonstruksi visual untuk memperoleh gambaran visual motif lokal tersebut.

\section{Poléng Camat}

Poléng Camat adalah motif poléng yang paling terkenal di Majalaya. Nama ini digunakan karena sarung ini populer dikalangan para camat di akhir tahun 1930-an. Disebutkan dalam sejarah, bahwa poléng camat dikembangkan oleh salah satu Srikandi Majalaya yakni Nyi Enda Suhaenda. Poléng camat digunakan sebagai media promosi industri tenun Majalaya, dan selalu digunakan dalam pertemuan - pertemuan formal dengan Bupati, atau dengan pejabat Hindia Belanda. Motif kotak dibentuk dari garis benang dengan warna khas kuning kunyit atau merah muda di atas warna dasar merah marun. Ciri khas warna ini menjadi pakem bagi poléng camat, selain bahan baku benang yang digintir sehingga nampak mengkilap dan mewah. Ukuran kotak berkisar antara $5-7 \mathrm{~cm}$. Proses dan hasil rekonstruksi visual motif Poléng Camat dapat dilihat pada Gambar 4 dan Gambar 5.

\section{Poléng Haji}

Poléng haji muncul di era tahun 1940-an. Istilah poléng haji digunakan karena kain ini menyerupai kain ihram, yakni kain putih yang digunakan saat ibadah haji. Kuota haji di zaman kolonialisme yang masih terbatas menyebabkan citra haji pada masa tersebut dipandang sebagai

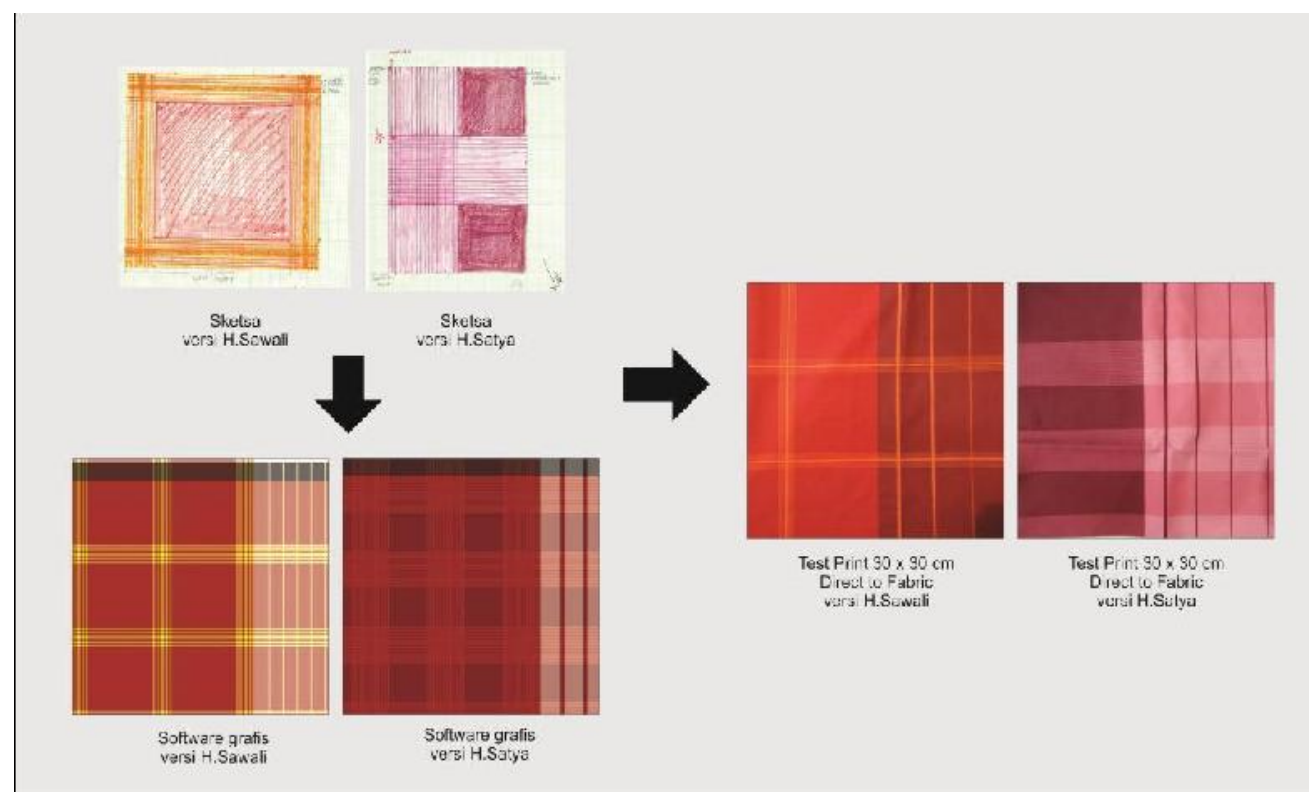

Gambar 4. Tahapan proses visualisasi motif Poléng Camat
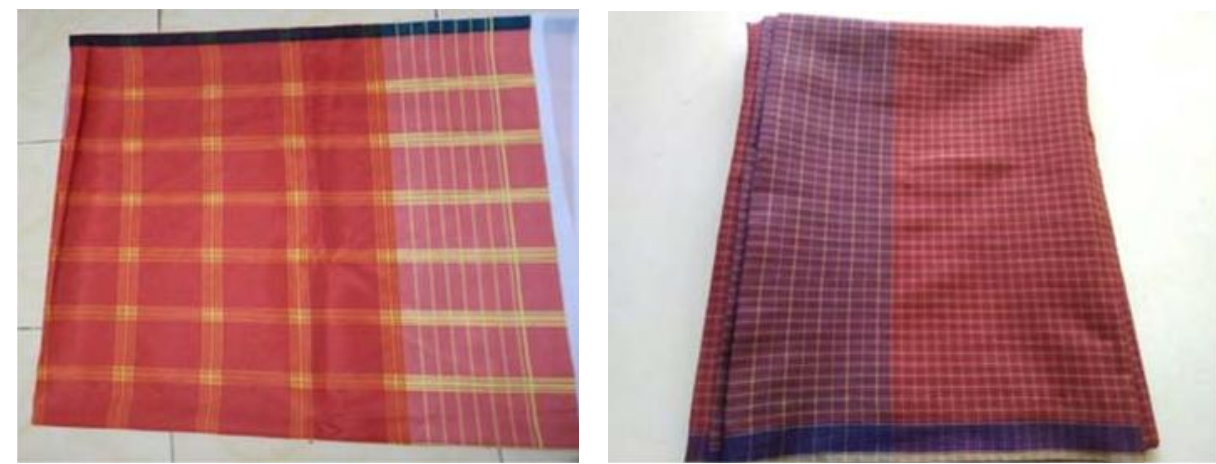

Gambar 5. a Motif Poléng Camat hasil rekonstruksi visual (kiri); b. Poleng Camat koleksi H. Oso Hambali (kanan) 
panutan (role model) masyarakat, sehingga membuat motif poléng ini banyak digunakan dikalangan para santri. Motif kotak terbentuk dari garis benang sederhana yang menggunakan warna berbeda. Ukuran kotak bervariasi, tidak ada aturan khusus. Salah satu contoh sarung Poléng Haji dapat dilihat pada Gambar 6.

\section{Poléng Totog}

Poléng totog adalah motif poléng yang berbeda dengan jenis poléng lainnya, hal ini disebabkan oleh bentuk motif yang khas seperti kain lurik. Arah salur memanjang kearah pakan sehingga ketika dipakai oleh penggunanya maka bentuk salur menjadi vertikal kearah tinggi kain sarung. Tidak ada aturan khusus mengenai ukuran lebar masing-masing salur. Garis- garis pada poléng totog dibentuk dari desain salur/strip horisontal. Tahapan rekonstruksi visual motif Poléng Totog dan hasil akhirnya dapat dilihat pada Gambar 7 dan 8.

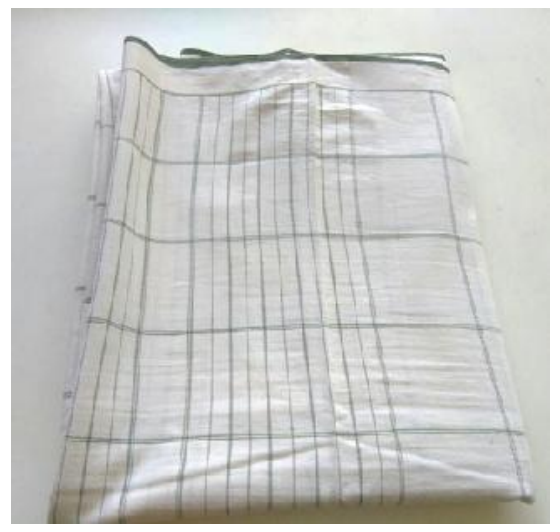

Gambar 6. Poléng Haji

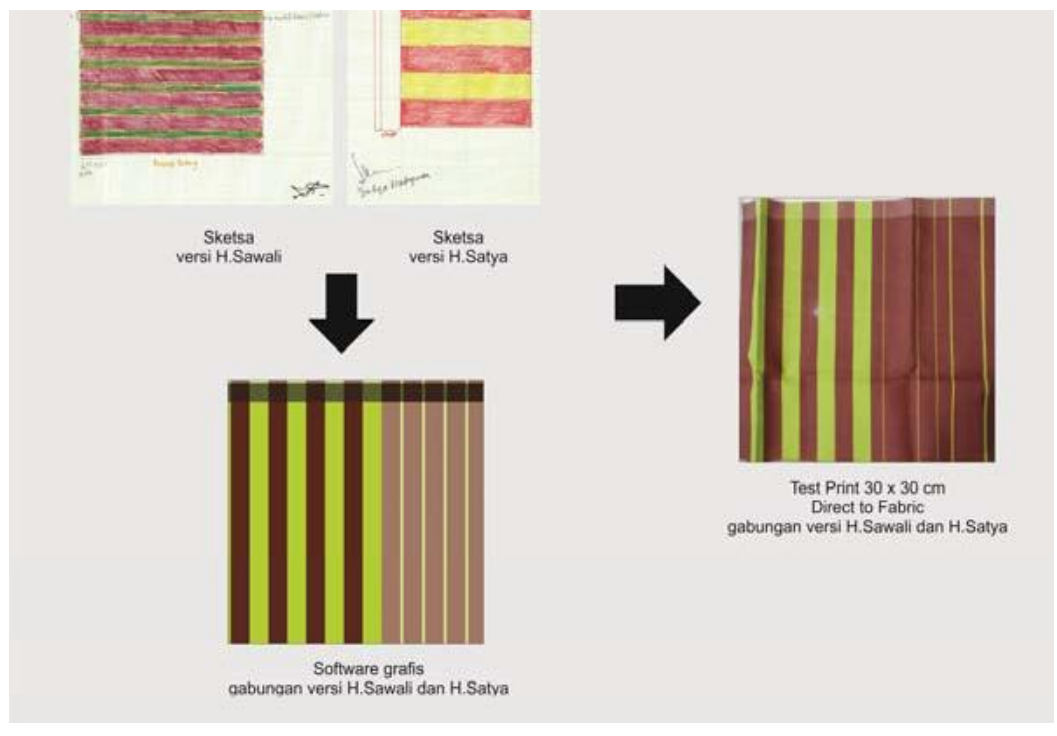

Gambar 7. Tahapan proses rekonstruksi visual motif Poléng Totog

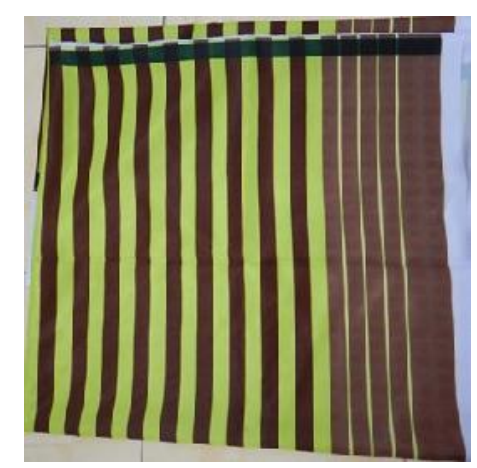

Gambar 8. Hasil akhir rekonstruksi visual motif Poléng Totog 


\section{Poléng Taliktik}

Poléng taliktik diyakini berasal dari kosa kata serapan Bahasa Sunda "leutik" yang artinya kecil-kecil, atau titik-titik. Bentuk motif berupa kotak-kotak berukuran 1,5 hingga $2 \mathrm{~cm}$ yang dasarnya motif kotak teratur. Ukuran kotak-kotak pada poléng taliktik lebih besar dibandingkan dengan motif kain "célé", yakni kain kotak-kotak yang biasanya digunakan sebagai kain busana kemeja. Tahapan proses rekonstruksi visual motif Poléng Taliktik beserta hasil akhirnya dapat dilihat pada Gambar 9 dan 10.

\section{Poléng Bolégbag}

Poléng bolégbag adalah istilah sarung yang memiliki motif kotak - kotak besar. Kotak dapat dipisahkan dengan menggunakan perbedaan warna atau dibentuk dari garis/strip benang. Ukuran kotak berkisar antara $10-30 \mathrm{~cm}$. Tahapan rekonstruksi visual motif Poléng Bolégbag dan hasil akhirnya dapat dilihat pada Gambar 12 dan 13.

\section{Poléng Namicalung}

Poléng Namicalung muncul akibat pengaruh sarung Samarinda. Namicalung dikenal sebagai kampung tenun legendaris di Majalaya. Karena pada awalnya salah satu pengusaha sarung di Namicalung yang berhasil membuat motif jenis ini, maka motif ini kemudian diberi nama Poléng Namicalung. Terdapat ciri khas sarung Samarinda yakni adanya unsur warna yang mencolok pada pertemuan garis. Ukuran kotak umumnya tidak lebih dari $5 \mathrm{~cm}$. Hasil rekonstruksi visual motif ini dapat dilihat pada Gambar 13.

Motif poléng Majalaya pada generasi pertama menggunakan anyaman polos (plain), sehingga permainan warna dan susunan benang lusi dan benang pakan menjadi alternatif dalam mengembangkan desain produk sarung. Meskipun motif poléng secara visual sama-sama dibentuk dari garis dan kotak-kotak, namun terdapat perbedaan karakter dari masing-masing motif tersebut. Perbedaan yang diamati terdapat pada ukuran kotak, jenis bahan baku, serta kategori motif desain

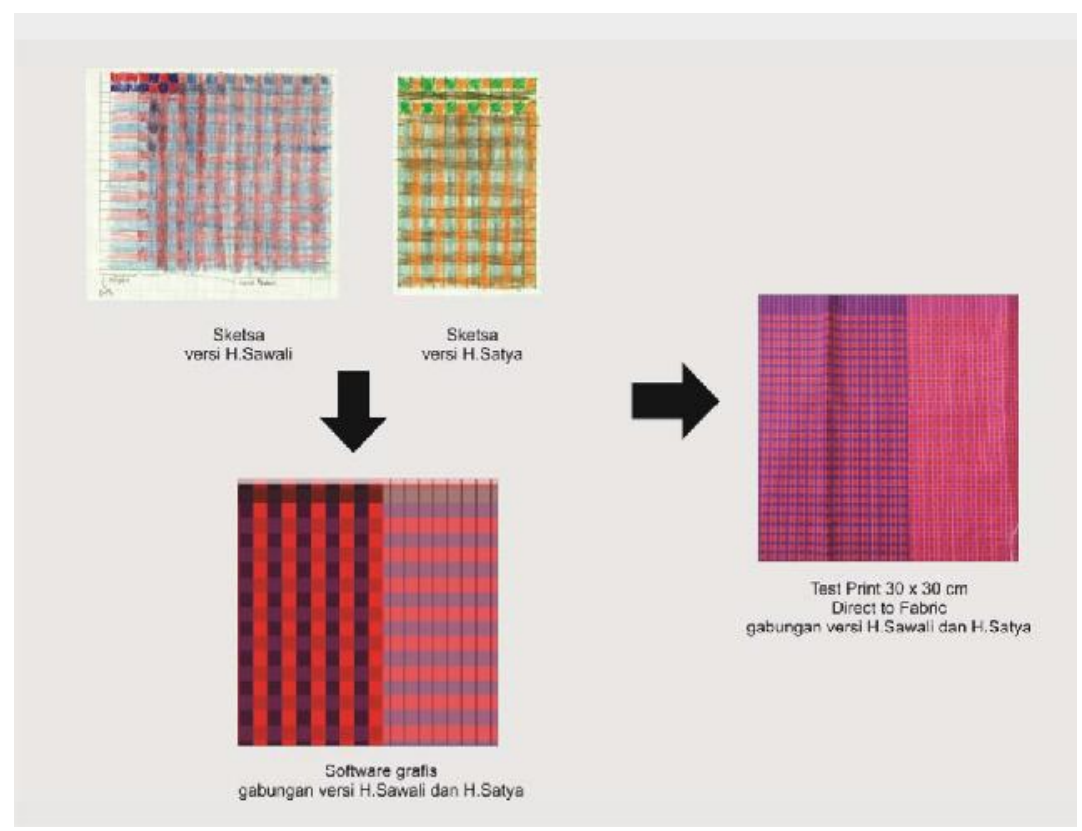

Gambar 9. Tahapan proses rekonstruksi visual motif Poléng Taliktik

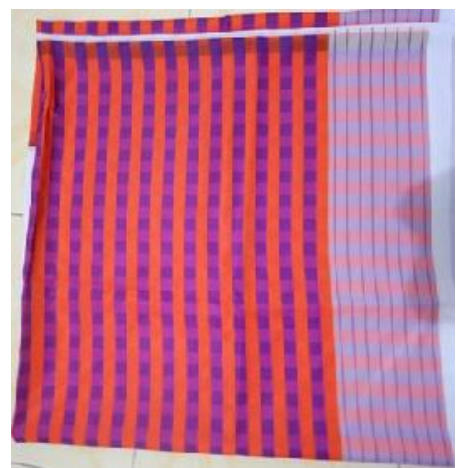

Gambar 10. Hasil akhir rekonstruksi visual motif Poléng Taliktik 
struktur yang diterapkan. Poléng camat merupakan sarung yang dianggap mewah pada masa itu, yang spesifik menggunakan benang gintir sehingga memiliki efek mengkilap, dengan ukuran kotak sekitar 5-7 cm. Poléng Haji warna dasar kain umumnya putih dengan garis-garis benang yang membentuk motif kotak menggunakan warna berbeda, dengan ukuran kotak variatif. Poléng totog tidak memiliki pakem ukuran, lebar antar garis bebas namun memiliki karakter salur seperti kain lurik. Poléng taliktik karakternya menyerupai

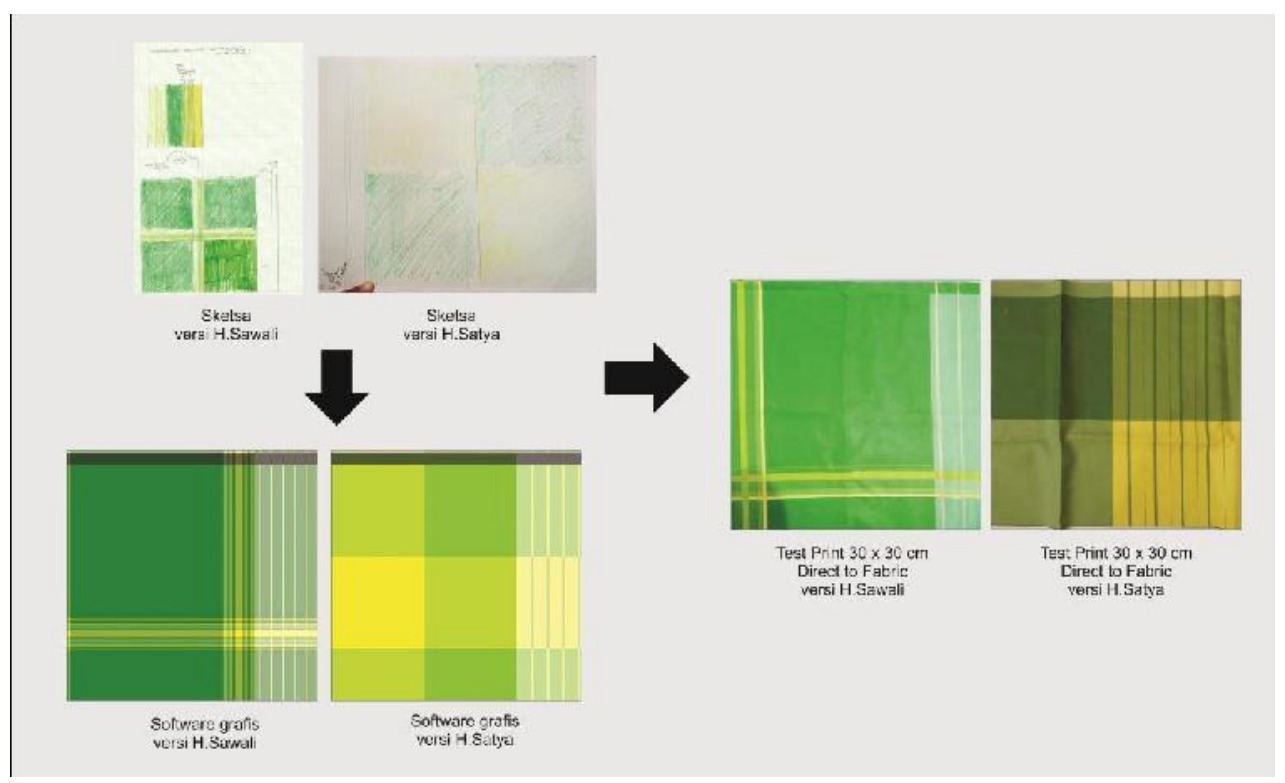

Gambar 11. Tahapan proses rekonstruksi visual motif Poléng Bolégbag

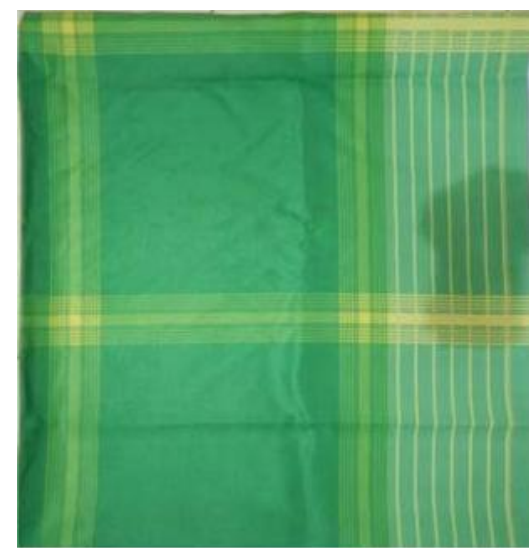

(a)

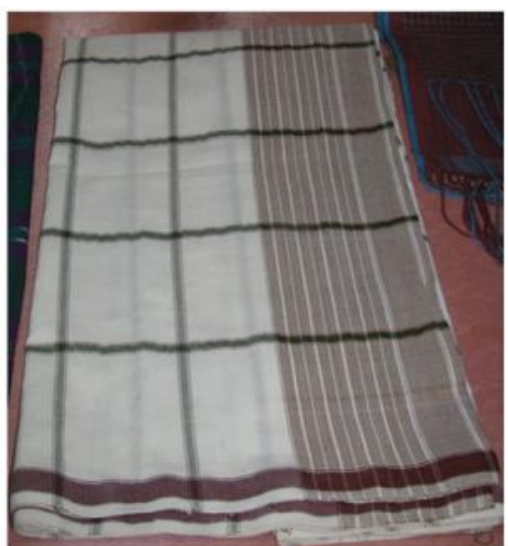

(b)

Gambar 12. a. Hasil akhir rekonstruksi visual motif Poléng Bolégbag (kiri) b. Sarung Poléng Bolégbag koleksi Museum Sribaduga (kanan)

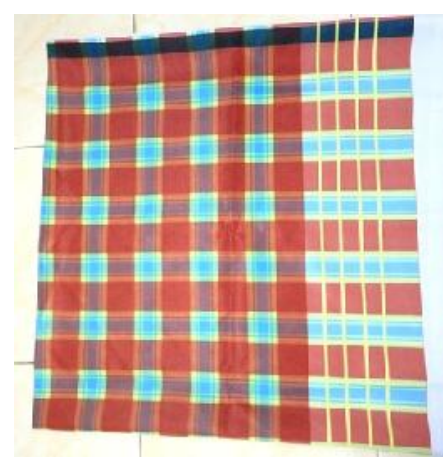

Gambar 13. Hasil rekonstruksi visual motif Poléng Namicalung 
kain kemeja célé, namun ukuran kotaknya lebih besar yakni sekitar $2 \mathrm{~cm}$. Motif dasarnya kotak beraturan tanpa strip/garis pemisah. Kotak dibentuk dari pertemuan dua warna yang berbeda. Poléng bolégbag menonjol dengan karakter kotak yang besar-besar, ukuran kotak 10-30 cm, motif kotak dibentuk dari garis/strip benang yang berbeda warna, atau dibentuk dari perbedaan warna pada motif dasar kotak beraturan. Poléng Namicalung yang dipengaruhi oleh sarung Samarinda dibuat dengan variasi warna yang lebih banyak sekitar 3-4 warna, dengan warna pada pertemuan garis umumnya lebih mencolok, dan ukuran kotak umumnya tidak lebih dari $5 \mathrm{~cm}$. Tabel 3 memberikan ringkasan dari pengamatan terhadap karakteristik desain motif sarung Poléng Majalaya. Terdapat hubungan antara motif dasar desain struktur, corak dasar Poléng Majalaya, dan aplikasi motif poléng generasi pertama. Hubungan berupa keterkaitan pola pengembangan motif sarung di Majalaya di era tahun 1930-an. Hal ini dapat dilihat melalui Gambar 14.

Tabel 3. Karakteristik desain motif sarung Poléng Majalaya

\begin{tabular}{|c|c|c|}
\hline Motif Poléng & Kategori Motif Dasar & Karakteristik \\
\hline Poléng Camat & $\begin{array}{l}\text { Desain kotak-kotak yang terbentuk } \\
\text { dari garis benang }\end{array}$ & 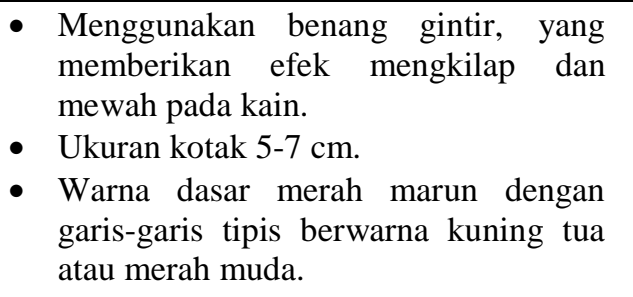 \\
\hline Poléng Haji & $\begin{array}{l}\text { Desain kotak yang terbentuk } \\
\text { dari garis benang }\end{array}$ & $\begin{array}{l}\text { - Terdiri dari dua warna. } \\
\text { - Ukuran kotak variatif. } \\
\text { - Warna dasar putih, dengan garis salur } \\
\text { menggunakan satu warna. }\end{array}$ \\
\hline Poléng Totog & Desain strip horizontal & $\begin{array}{l}\text { - Terdiri dari dua warna. } \\
\text { - Jarak lebar masing-masing garis bebas. } \\
\text { - Corak salur ke arah pakan, sehingga } \\
\text { jika digunakan maka arah salur menjadi } \\
\text { vertikal. Tidak menggunakan garis } \\
\text { pembatas. }\end{array}$ \\
\hline Poléng Taliktik & Desain kotak teratur & $\begin{array}{l}\text { - } \text { Corak dadu/persegi. } \\
\text { - Ukuran kotak sekitar } 2 \mathrm{~cm} \text {. } \\
\text { - Tidak menggunakan garis pembatas } \\
\text { (hanya pergantian warna saja) }\end{array}$ \\
\hline Poleng Bolégbag & $\begin{array}{l}\text { Desain kotak teratur / Desain } \\
\text { kotak- kotak yang terbentuk dari } \\
\text { garis benang }\end{array}$ & $\begin{array}{l}\text { - } \text { Corak dadu/persegi. } \\
\text { - Ukuran kotak antara } 10-30 \mathrm{~cm} \text {. } \\
\text { - Kotak terbentuk dari pergantian warna } \\
\text { lusi dan pakan, atau warna dasar satu } \\
\text { warna dan kotak dipisahkan oleh garis }\end{array}$ \\
\hline Poléng Namicalung & Desain plaid & $\begin{array}{l}\text { - } \text { Menggunakan 2-3 warna. } \\
\text { - } \quad \text { Ukuran kotak di bawah } 5 \mathrm{~cm} \text {. } \\
\text { - } \text { mencomuan garis biasanya warnanya } \\
\text { dibandingkan warna dasarnya }\end{array}$ \\
\hline
\end{tabular}




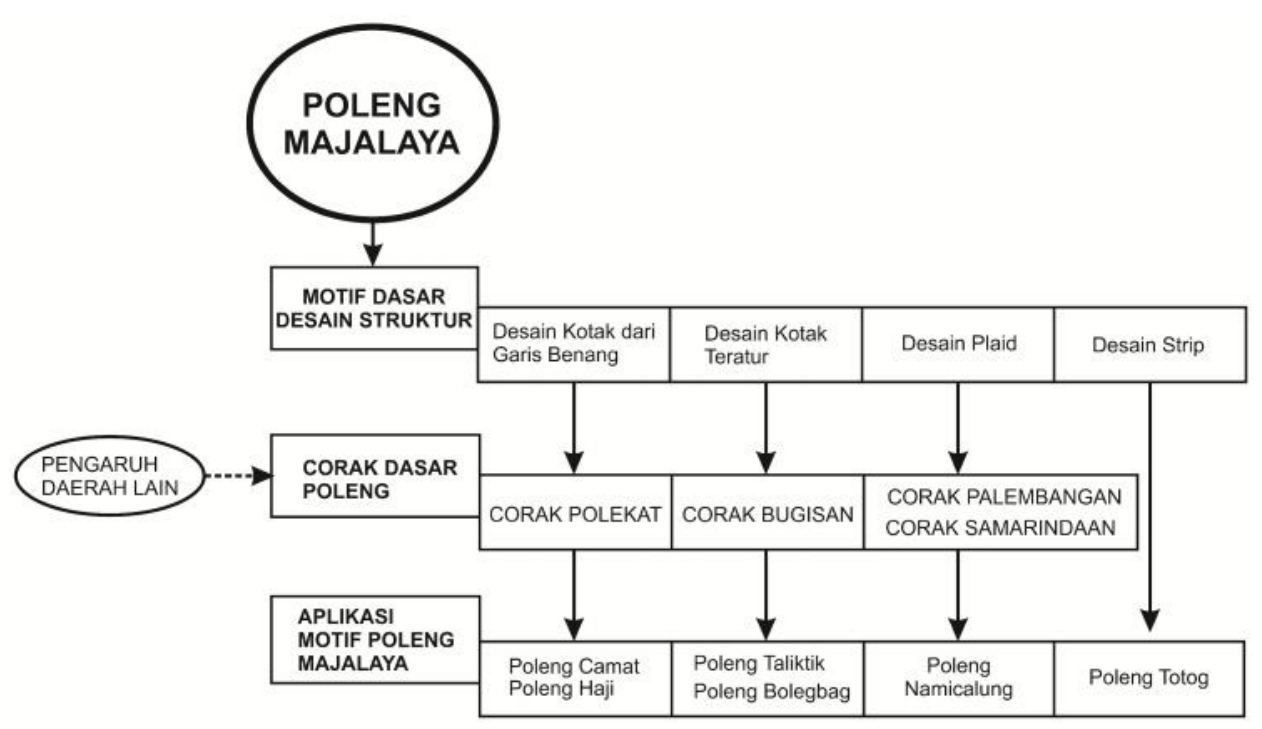

Gambar 14. Hubungan antara motif dasar desain struktur, corak dasar Poléng Majalaya dan aplikasi motif Poléng Majalaya generasi pertama

\section{KESIMPULAN}

Dari rangkaian kegiatan yang telah dilakukan dapat disimpulkan bahwa meskipun Majalaya tidak memiliki ragam hias tenun yang muncul dari filosofi tradisi budaya lokal, namun pada awal kejayaan sarung tenun generasi pertama tahun 1930-1970 motif poléng muncul sebagai motif khas sarung Majalaya. Pada awalnya motif ini hanya dikenal dengan sebutan Poléng Majalaya, namun dalam perkembangannya motif poleng diberi nama-nama khusus yang sarat dengan identitas lokal Jawa Barat. Dari penelusuran di lapangan ditemukan setidaknya enam motif poléng yang dikenal dikalangan produsen sarung Majalaya, motif tersebut adalah: (1) poléng camat, (2) poléng haji, (3) poléng totog, (4) poléng taliktik, (5) poléng bolégbag, dan (6) poléng namicalung. Keenam motif tersebut dikembangkan dari empat corak dasar sarung Majalaya yang dikenal saat itu, yaitu corak Palembangan, corak Polekat, corak Bugisan, dan corak Samarindaan. Terdapat hubungan pola pengembangan motif antara motif dasar desain struktur, corak dasar Poléng Majalaya, dan aplikasi motif poléng generasi pertama.

Motif poléng pada dasarnya merupakan aplikasi dari desain motif garis dan kotak-kotak yang merupakan motif dasar desain struktur pada kain tenun. Dalam hal ini baik kategori desain motif garis dan kotak milik Zheng (2013) dan Jumaeri,dkk. (1974) sama- sama dapat diterapkan untuk mengklasifikasikan motif sarung poléng.

Metode rekonstruksi visual dapat dijadikan salah satu solusi yang ditempuh dalam penelitian sejarah apabila dokumentasi visual sebuah produk/artefak tidak berhasil ditemukan karena hilang atau rusak. Tahapan yang terpenting adalah upaya mengeluarkan ingatan masa lalu informan menggunakan alat bantu ingat (mnemonic devices), dan menuangkan ingatan kedalam rekonstruksi visual motif masa lalu dalam bentuk gambar dan replika produk. Kombinasi metode folklor non-lisan dengan teknik rekonstruksi visual ini terbukti dapat digunakan dalam penelitian bidang desain dan kriya tekstil, dan dapat dimanfaatkan untuk menggali dan mengungkap motif-motif tradisional yang sudah lama hilang.

\section{SARAN}

Hasil penelitian ini masih berupa studi awal yang perlu dilanjutkan dalam rangka mengungkap motif- motif sarung Majalaya lainnya yang masih belum ditemukan saat ini dengan cara menggali lebih banyak ingatan masa lalu dari informan yang lebih luas. Hasil rekonstruksi visual melalui ini dapat ditindaklanjuti dengan meneliti komposisi dan konstruksi kain sehingga dapat diaplikasikan pada mesin tenun. Nomenklatur bahasa lokal seperti poléng dan coréléng memiliki potensi untuk diangkat kembali menjadi nama motif khas sarung Majalaya.

\section{UCAPAN TERIMAKASIH}

Ucapan terimakasih yang sebesar-besarnya Peneliti sampaikan pada Pusat Pendidikan dan Latihan Industri Kementerian Perindustrian RI atas dana beasiswa Mandiri jenjang S-2 yang diberikan selama Peneliti menyelesaikan program Magister Desain di Institut Teknologi Bandung.

\section{PUSTAKA}

1. Anas, B., et al. Indonesia Indah 10: Busana Tradisional. Jakarta: Yayasan Harapan Kita (1998).

2. Keppy, P. Hidden Business: Indigenous and Ethnic Chinese Entrepreneurs in the Majalaya. (2001) 
3. Textile Industry, West Java, 1928-1974. Dissertation. Amsterdam: Vrije Universiteit.

4. Setia, R. Gali Tutup Lubang Itu Biasa: Strategi Buruh Menanggulangi Persoalan dari Waktu ke Waktu. Bandung: Yayasan AKATIGA. (2005).

5. Hardjono,J. Developments in The Majalaya Textile Industry. West Java Rural Nonfarm Sector. (1990).

6. Research Project Series No.B-3. Bandung: PSP-IPB,ISS,PPLH-ITB.

7. Moeliono, M. Konsep Prinsip Proses Dasar Desain Pertenunan. Bandung: Penerbit ITB (2016).

8. Jumaeri, et al. Textile Design. Bandung: Institut Teknologi Tekstil (1974).
9. Intani, R. Menelusuri Kejayaan Tenun Majalaya: Mengungkap Sejarah, Sistem Teknologi, Sistem Ekonomi, dan Sosial Budaya). Laporan Penelitian Tahun 2002. Bandung: Balai Kajian Sejarah dan Nilai Tradisional (2002).

10. Zheng, X. A Study on Striped and Checked Patterns in Silk Fabric of the Republic of China (19121949). Asian Social Science 9 (15), 72-83 (2013).

11. Soeparli, L. et al. Teknologi Pertenunan. Bandung: Institut Teknologi Tekstil (1973).

12. Dienaputra, R.D Sejarah Lisan: Konsep dan Metode. Bandung: Minor Books (2006).

13. Danandjaya, J. Folklor Indonesia: ilmu gosip, dongeng dan lain-lain. Jakarta: PT. Pustaka Utama Grafiti (2007). 